\title{
Degassers in drinking water supply
}

\author{
Larisa Belova ${ }^{1, *}$, Alexandr Zhulin ${ }^{1}$, Olga Sidorenko ${ }^{1}$ \\ ${ }^{1}$ Federal State Budget Educational Institution of Higher Education «Industrial University of \\ Tyumen»/ IUT, 2, 625001, Tyumen, Russia
}

\begin{abstract}
In the Tyumen region, groundwater is widely used for household and drinking water supply, the chemical composition of which is influenced by the increased marshland and peat resistance of soils and, in some cases, the presence of oil and gas-bearing horizons. Underground water typically has a high content of dissolved organic impurities (permanganate oxidability 11.7 - 23.0 $\left.\mathrm{mg} / \mathrm{dm}^{3}\right)$, elevated concentrations of free carbon dioxide $(20.0$ $\left.200.0 \mathrm{mg} / \mathrm{dm}^{3}\right)$, hydrogen sulfide $\left(0.20-1.95 \mathrm{mg} / \mathrm{dm}^{3}\right)$ and methane $\left(5.3-60.0 \mathrm{mg} / \mathrm{dm}^{3}\right)$, dissolved forms of iron $(1.14-14.00$ $\left.\mathrm{mg} / \mathrm{dm}^{3}\right)$, manganese $\left(0.02-3.80 \mathrm{mg} / \mathrm{dm}^{3}\right)$.

Analysis of iron removal plants operation was performed. Analysis of the region's iron removal plants showed that the process of iron removal of water depends on the degree of saturation of water with air oxygen with parallel removal of dissolved gases. Pre-degassing of water with high efficiency degassers is a necessary link of the process chain even when reagent purification techniques are used.

Analysis and systematization of existing degassers to remove dissolved carbon dioxide have shown that despite the highefficiency of some degasser models, they are complex in design and require considerable capital construction and operation costs. There is a need to develop a design not complicated in design, having high degassing efficiency at low economic costs.
\end{abstract}

\section{Introduction}

The chemical composition of water is determined by the natural conditions in which its cycle is carried out and determined by physical-geographical, geological, physicalchemical, biological, and anthropogenic factors [1]. All-natural waters contain some amount of gases from several $\mathrm{mg} / \mathrm{dm}^{3}$ to $\mathrm{n} \times 10^{3} \mathrm{mg} / \mathrm{dm}^{3}$.

Earth crust gases, as a result of diffusion and filtration processes, can migrate through cracks and pores of rocks, enter aquifers, dissolving in water. By quantitative prevalence in groundwater, the gases are presented in the following order: carbon dioxide $\mathrm{CO}_{2}$, hydrogen sulfide $\mathrm{H}_{2} \mathrm{~S}$, methane $\mathrm{CH}_{4}$, nitrogen $\mathrm{N}_{2}$, small accumulations of dense hydrocarbon gases, radon, argon, helium, and hydrogen are possible [2, 3].

*Corresponding author: klv.72@mail.ru 
Gases are divided into two water solubility groups:

1) gases with non-polar molecules that dissolve poorly in water - nitrogen, oxygen, argon, etc.;

2) gases with polar molecules, which upon interaction with water form chemical compounds capable of electrolytic dissociation - carbon dioxide and hydrogen sulfide.

The solubility of gases in water depends on the nature of the gas itself, pressure, temperature, the mineralisation of water. The partial pressure of carbon dioxide in the air is $30-40 \mathrm{~Pa}$, and according to Henry-Dalton 's law, its concentration in water can range from 0.5 to $1.3 \mathrm{mg} / \mathrm{dm}^{3}[4,5]$.

According to the gas genesis classification, carbon dioxide can be atmospheric, biochemical, chemical, or one is mantle degassing gas.

In closed hydrogeochemical systems, water saturation with carbon dioxide is carried out at infiltration through the soil layer due to biochemical processes. The life activity of microorganisms accelerates redox processes, contributing to change of valence of many chemical elements, as a result of which reliable components are transferred into liquid phase, which increases their migration capacity [6]. For example, under anaerobic conditions with significant concentrations of organic substances in groundwater, they are oxidised by microorganisms to form carbon dioxide and methane [7]

$$
\begin{gathered}
\mathrm{C}_{6} \mathrm{H}_{12} \mathrm{O}_{6}+6 \mathrm{H}_{2} \mathrm{O} \rightarrow 6 \mathrm{CO}_{2}+12 \mathrm{H}_{2}, \text { then } \\
\mathrm{CO}_{2}+4 \mathrm{H}_{2} \rightarrow \mathrm{CH}_{4}+2 \mathrm{H}_{2} \mathrm{O}
\end{gathered}
$$

Methane is poorly reacted with water due to low solubility.

The oil and gas origin of carbon dioxide is associated with gas and oil fields. The release of dissolved gases occurs from oil as formation pressure decreases. Scattered hydrocarbon gases in rocks of oil and gas areas migrate and accumulate in horizons of awkward water exchange [8].

By reacting the $\mathrm{CO}_{2}$ with water, unstable carbonic acid is formed $\mathrm{H}_{2} \mathrm{CO}_{3}$ with the structural formula of the molecule, which refers to weak electrolytes and exists only in aqueous solution, giving it an acidic taste. Of the total dissolved $\mathrm{CO}_{2}$, only $0.3 \%$ reacts with water to form carbonic acid, the remainder being free.

The hydration reaction of carbon dioxide is slow compared to the dissociation of carbonic acid and depends on the $\mathrm{pH}$ of the solution, at $\mathrm{pH}=4.3$ all carbon dioxide is in the form of free carbon dioxide $\mathrm{CO}_{2}$ and its hydrated form $\mathrm{H}_{2} \mathrm{CO}_{3}$, at $\mathrm{pH}=8.35$ practically all in the way of bicarbonate ions, and at $\mathrm{pH}$ increase to 12 is represented only by carbonate ions [9].

The dissociation constants of carbonic acid depend on the water temperature, with the hydration rate constant decreasing $\mathrm{CO}_{2}$ and the dissociation constants of the first and second stages increasing [10].

The bicarbonate, carbonate, carbon dioxide ions contained in the water are linked by carbon dioxide equilibrium

$$
2 \mathrm{HCO}_{3}^{-} \Leftrightarrow \mathrm{CO}_{3}^{2-}+\mathrm{CO}_{2}+\mathrm{H}_{2} \mathrm{O}
$$

According to equation (3), equilibrium carbon dioxide is necessary to maintain a certain amount of bicarbonate ions $\mathrm{HCO}_{3}^{-}$in the solution. If in water $\mathrm{CO}_{2}>>\mathrm{CO}_{2}^{e q}$, its excess is capable of causing the dissolution of calcium carbonate (aggressive water), if so $\mathrm{CO}_{2}<<\mathrm{CO}_{2}^{e q}$, a portion of the bicarbonate ions will decay to form $\mathrm{CO}_{2}$. 
Chemically unbound and chemically bound carbon dioxide is distinguished, denoting in chemical analysis total $\left(\mathrm{H}_{2} \mathrm{CO}_{3}, \mathrm{CO}_{2}, \mathrm{HCO}_{3}^{-} u \mathrm{CO}_{3}^{2-}\right)$, free (aggressive plus equilibrium $=\mathrm{H}_{2} \mathrm{CO}_{3}+\mathrm{CO}_{2}$ ), carbonate (bound as ions $\mathrm{CO}_{3}^{2-}$ ), hydrogen carbonate (semi-bound as ions $\mathrm{HCO}_{3}^{-}$) [11].

The carbonic acid content in water is not regulated by SanPiN 2.1.4.1074-01, but in water supply practice, its removal or binding is required. As coal acid negatively influences processes of iron and manganese removal, coagulation, softening, desalting, stabilisation of water $[10,12,13,14,15,16]$.

Dissolved iron in the underground water of the region is present mainly as $\mathrm{Fe}\left(\mathrm{HCO}_{3}\right)_{2}$, the stability of the compound depends on the presence of carbon dioxide and oxygen. For oxidation of $1 \mathrm{mg}$ of iron (II) stoichiometrically according to the equation

$$
4 \mathrm{Fe}^{2+}+\mathrm{O}_{2}+8 \mathrm{HCO}_{3}{ }^{-}+2 \mathrm{H}_{2} \mathrm{O}=4 \mathrm{Fe}(\mathrm{OH})_{3} \downarrow+8 \mathrm{CO}_{2} \uparrow
$$

$0.143 \mathrm{mg}$ of oxygen is consumed, and $0.036 \mathrm{mmol} / \mathrm{dm}^{3}$ reduces the alkalinity of the water, and $1.6 \mathrm{mg}$ of $\mathrm{CO}_{2}$ is released $[10,17,18]$.

The choice of the method of iron removal depends on the concentration and form of iron in the water (ferrous ions, colloidal organic and inorganic compounds, truly dissolved organic iron compounds) [19].

Simplified aeration with filtration is widely used in the region. Iron removal in simplified aeration is a heterogeneous autocatalytic process, does not require oxidation of divalent iron to trivalent before filtration, allows to eliminate special aeration devices and contact tanks, reduces capital and operating costs. Water is saturated with oxygen with simultaneous removal of free carbon dioxide by pouring water or supplying air into the treated water.

In case of insufficient removal of free carbon dioxide, its molecules are concentrated on the surface of the catalytic film of the iron removal filter loading, disrupting iron oxidation processes due to lack of contact of water with the film. The free carbon dioxide formed during iron removal leads to a local decrease of $\mathrm{pH}$, slow oxidation and hydrolysis, with possible local dissolution of unstable di- and trivalent iron hydroxides [19, 20].

Authors noted that carbon dioxide imparts minimal acidity to water. Still, the effect of carbonic acid on steel is more considerable than strong hydrochloric acid due to the buffering properties of the $\mathrm{CO}_{2}$ solution. In small concentrations, free carbon dioxide has an indirect effect on the corrosion process, preventing the precipitation of carbonate precipitate, which can significantly inhibit corrosion. At high content of free carbon dioxide and low $\mathrm{pH}$ values of the water corrosion process with oxygen and hydrogen depolarization is accelerated.

As a result of the corrosion of pipelines, the content of iron in water increases during its transportation, the capacity of pipelines is reduced, electricity consumption increases to create the necessary pressure in the network, the fistula may appear, and water leakage occurs $[22,23,24,25]$.

Increased concentrations of carbon dioxide reduce the capacity of high-base anionites for silicic acid ions and require increased consumption of sodium hydroxide during their regeneration, make it necessary to include decarbonizers of water between the stages of ion-exchange filters to remove $\mathrm{CO}_{2}$, increasing capital and operating costs $[21,26]$.

Further studies consider the removal of excess (aggressive) free carbon dioxide. 


\section{Materials and Methods}

The methodological basis of the study is theoretical methods of research - observation, analysis, comparison, generalization. The theoretical basis is the scientific works of specialists in the field of water degassing for the needs of household and drinking water supply and other industries.

Degassing methods on the principle of influence on treated water are divided into three groups - chemical, biochemical and physical.

To bind carbon dioxide by chemical method, alkali (lime, sodium hydroxide) is used, at the same time carbon dioxide is transferred first to bicarbonate ion and then to carbonate ion, according to equations [27]

$$
\begin{gathered}
\mathrm{NaOH}+\mathrm{CO}_{2}=\mathrm{NaHCO}_{3}, \\
\mathrm{NaHCO}_{3}+\mathrm{NaOH}=\mathrm{Na}_{2} \mathrm{CO}_{3}+\mathrm{H}_{2} \mathrm{O}, \\
\mathrm{Ca}(\mathrm{OH})_{2}+\mathrm{CO}_{2}=\mathrm{Ca}\left(\mathrm{HCO}_{3}\right)_{2}, \\
\mathrm{Ca}\left(\mathrm{HCO}_{3}\right)_{2}+\mathrm{Ca}(\mathrm{OH})_{2}=2 \mathrm{CaCO}_{3}+2 \mathrm{H}_{2} \mathrm{O} .
\end{gathered}
$$

Chemical methods of carbon dioxide elimination in the domestic and drinking water supply are not used due to their labour intensity, high cost and the need to strictly observe the dosage of reagents [28].

Physical methods based on the Henry-Dalton Act, according to which the amount of dissolved gas depends on the amount of its partial pressure over the solution and the temperature of the water, have become widespread in the practice of water degassingaeration. The partial pressure of many gases, in particular carbon dioxide, in atmospheric air is close to zero, so when water and air contact due to the difference in partial pressures of the removed gas, its molecules transition from liquid to air (desorption).

Authors noted that «There are two main types of aerators in general use: those in which water is allowed to fall through air, for example, free-fall aerators, packed tower aerators and spray aerators, and those in which air is injected into water, for example injection aerators, diffused air-bubble aerators and surface aerators» [29].

Physical degassing methods include: 1) simplified aeration - free pouring, spraying above the water surface (without and with forced air supply), spray plants; 2) simplified aeration in the pressure version; 3) packed degassers (without and with forced air supply); 4) ejection degassing-aeration; 5) bubbling (in free volume, double action, foam type, with gravel loading); 6) vortex deaeration (without and with forced air supply); 7) vacuum; 8) thermal; 9) ultrasonic; 10) wave degassing. Ejection, thermal, vacuum deaeration are used mainly in thermal power engineering, wave degassing [30] is under research.

\section{Results}

\subsection{Analysis of iron removal plants in the Tyumen region}

In the Tyumen region, iron removal plants were previously introduced, operating according to the method of simplified aeration with filtration on pressure grainy filters, which did not always provide the required degree of water purification [31, 32, 33, 34, 35, 36, 37], which was the reason for analysis of the current technological purification schemes.

As a result of studies carried out by the Research Institute of KVOV to improve the treatment of groundwater for Nefteyugansk, a complex technological scheme for water treatment was proposed, including degassing, ozonation, coagulation, filtration on sand and 
coal filters, water decontamination (Fig.1). The authors of the project of reconstruction of the plant ("MosvodokanalNII Project") found that along with the use of reagents, preliminary aeration of water on degasators-aerators is a necessary stage of water treatment for removal of the main mass of free gases $\left(\mathrm{CO}_{2}\right.$ and $\left.\mathrm{CH}_{4}\right)$, which allows to achieve the required iron content and increase the efficiency of subsequent reagent treatment of water [31].

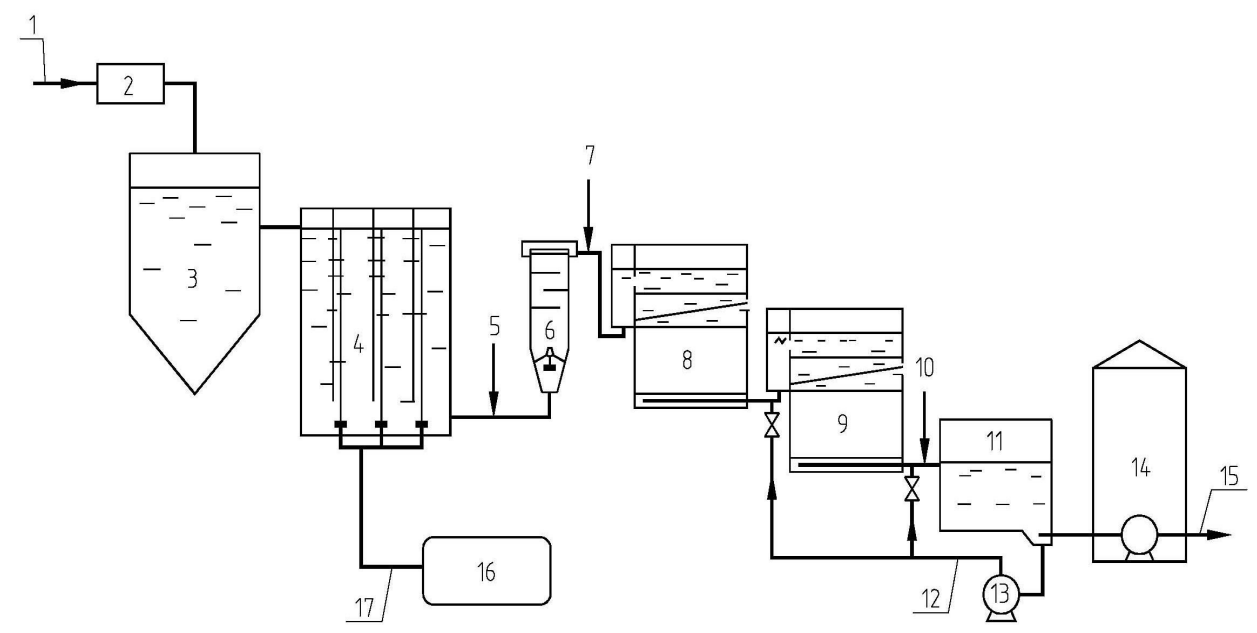

Fig. 1. Basic diagram of groundwater treatment for Nefteyugansk [31]: 1 - supply of source water from the well; 2 - high-efficiency aerator; 3 - degasser-aerator; 4 - contact chamber; 5 - coagulant supply; 6 - mixer; 7 - flocculant supply; 8 - fast filter with two-layer loading; 9 - coal filter; 10 chlorine agent supply; 11- is a clean water tank; 12 - a water supply for filter washing; 13 - washing pump; 14 - lifting pump station II; 15 - water supply to the consumer; 16 - ozonator unit; 17 supply of ozone-air mixture.

In Kogalym for effective iron removal cleaning according to the following scheme was offered: supply of initial water in aeration and degasser installation $\rightarrow$ filtering through hydroanthracite $\rightarrow$ a dookisleniye oxygen in the mixture camera $\rightarrow$ filtering through Evrezit anthracite $\rightarrow$ disinfecting [32].

It is offered to purify underground waters of the Hugotsky water intake of Nyagan with small salinity, high content of aggressive carbonic acid, iron and manganese according to the technological scheme: water stabilization by calcium hydroxide $\rightarrow$ iron and manganese removal on two-level sedimentation -sorption filters with floating and heavy loadings $\rightarrow$ disinfecting by hypochlorite of calcium or sodium $\rightarrow$ fluoridation [35].

At the Cedar Log water treatment plant in Surgut, water aeration was carried out according to two schemes. According to the first scheme, a fan cooling tower was used as an aerator-degasser, followed by additional oxidation of iron in an intermediate tank for 30 minutes, and formation of a catalytic film in the filter charge was disturbed, which reduced the effect of iron removal.

According to the second purification scheme, it was supplied through a reduction valve upstream of the mixer to saturate the water with air oxygen, after which the water was supplied to the pressure filters. The absence of a degasser in this scheme leads to a build-up of gases in the filter charge and impairs the iron removal process. In order to increase the efficiency of work, the stations were reconstructed: according to the first scheme, the wooden chord nozzle was replaced with a nozzle of plastic blocks of prisms with a height of $0.5 \mathrm{~m}$ (the degassing effect increased by $15 \%$ ); In the second scheme, a bubbling aerator degassing device (Fig.2) was activated, which provided a stable effect on methane and iron removal [37]. 


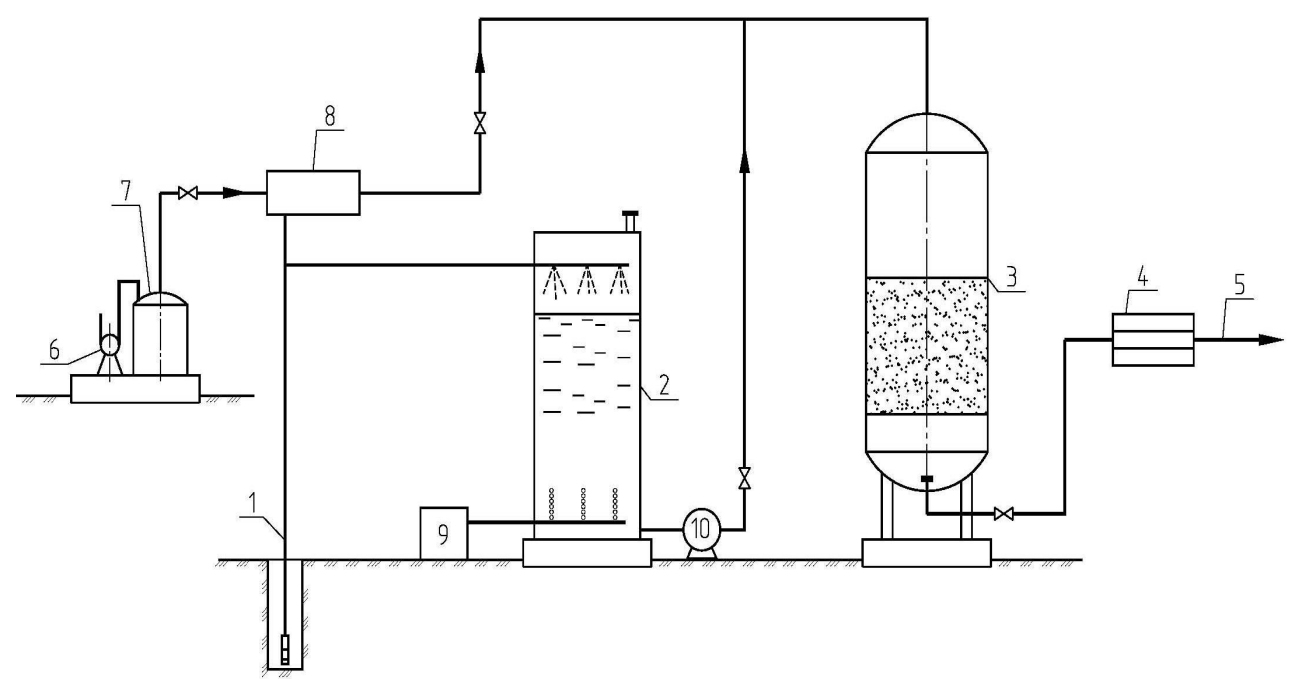

Fig. 2. Basic diagram of groundwater treatment for Surgut [37]: 1 - supply of source water from the well; 2 - bubbling degasser-aerator; 3 - pressure filter; 4 - bactericidal unit; 5 - water supply to the consumer; 6 - compressor; 7 - receiver; 8 - mixer; 9 - turbocompressor; 10 - pump.

The underground source of household and drinking water supply of the Tyumen Rehabilitation Center "Taraskul" contains high concentrations of iron (up to $14 \mathrm{mg} / \mathrm{dm}^{3}$ ) and dissolved carbon dioxide (up to $200 \mathrm{mg} / \mathrm{dm}^{3}$ ). The station is made according to the scheme of two-stage filtering (contact and mechanical filters) in the pressure version, air was supplied to the mixer installed before the filters, which did not ensure sufficient mixing of water with air, the efficiency of carbon dioxide removal was not more than $5-10 \%$. It was proposed to increase the amount of air supplied, replace the mixer-aerator and install an air sampler to remove excess air accumulated in the filter load [38]. As a result of the change in mixer design and removal of excess air, the concentration of iron in the water after the filters was $0.5-0.6 \mathrm{mg} / \mathrm{dm}^{3}$, further reduction of iron concentration under this scheme is not possible due to the presence of iron-organic complexes in the water.

Based on studies and the introduction of various technologies of groundwater treatment in the region, the fields of application of methods of purification and iron removal were determined: reactive - at the low colour of the water; reagent - at medium and high chromaticity due to the presence of humic compounds. Due to the presence of free gases in almost all aquifers, degassing of water is necessary [34, 35].

Degassing efficiency for different objects of the region under different methods of water aeration is shown in Table 1. [38]. 
Table 1. Degassing efficiency for different objects in the region.

\begin{tabular}{|c|c|c|c|c|c|}
\hline Object & $\begin{array}{c}\text { aeration } \\
\text { Types }\end{array}$ & $\begin{array}{c}\text { the } \\
\text { Consumption of } \\
\text { air, } \mathrm{m}^{3} / \mathrm{m}^{3}\end{array}$ & $\begin{array}{c}\text { Quantity of } \\
\mathrm{CO}_{2} \text { in ref. } \\
\text { water, } \\
\mathrm{mg} / \mathrm{dm}^{3}\end{array}$ & $\begin{array}{c}\text { Quantity of } \\
\mathrm{CO}_{2} \text { in water } \\
\text { of } \mathrm{mg} / \mathrm{dm}^{3}\end{array}$ & $\begin{array}{c}\text { Effect of } \\
\text { removal of } \\
\mathrm{CO}_{2}, \%\end{array}$ \\
\hline P. Tarascul & $\begin{array}{c}\text { simplified In } \\
\text { pressure } \\
\text { mode }\end{array}$ & 4 & 100 & 60 & 40 \\
\hline Poykovsky & $\begin{array}{c}\text { "dry" } \\
\text { filtration }\end{array}$ & 4 & $62-79$ & $37-58$ & $12-36$ \\
\hline $\begin{array}{l}\text { Velijans P. } \\
\text { (Tyumen) }\end{array}$ & $\begin{array}{l}\text { bubbling } \\
\text { In free } \\
\text { volume }\end{array}$ & 3 & 120 & 68 & 43 \\
\hline Onoquino $^{1}$ & simplified & - & 100 & 56 & 44 \\
\hline Yalutorovsky & simplified & 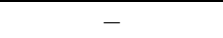 & 65 & 52 & 20 \\
\hline $\begin{array}{c}\text { Khanty- } \\
\text { Mansiysk } \\
\text { (C/w North) }\end{array}$ & $\begin{array}{l}\text { simplified In } \\
\text { pressure } \\
\text { mode }\end{array}$ & 0,1 & 31 & 25 & 20 \\
\hline $\begin{array}{c}\text { Khanty- } \\
\text { Mansiysk } \\
\text { (H/w South) }\end{array}$ & $\begin{array}{c}\text { Bubbling } \\
(5 \mathrm{~min})\end{array}$ & 1 & 86 & 43,5 & 49,4 \\
\hline P. Gubkin & bubbling & 12 & 60 & 10 & 83 \\
\hline Surgut & $\begin{array}{c}\text { bubbling } \\
\text { (5 min) }\end{array}$ & 5 & 40 & 24 & 40 \\
\hline Surgut & $\begin{array}{c}\text { Cooling } \\
\text { Tower Fan }\end{array}$ & - & $54-67$ & $22-36$ & $40-53$ \\
\hline Salekhard & $\begin{array}{c}\text { contact } \\
\text { cooling } \\
\text { tower }\end{array}$ & - & 30 & 20 & 33 \\
\hline Novotarmansk & $\begin{array}{l}\text { Simplified } \\
\text { In pressure } \\
\text { mode }\end{array}$ & 2 & 90 & 55 & 26 \\
\hline G. Langepas & $\begin{array}{l}\text { simplified } \\
\text { In pressure } \\
\text { mode }\end{array}$ & 1 & 100 & 80 & 20 \\
\hline Lantor & $\begin{array}{l}\text { contact } \\
\text { cooling } \\
\text { tower }\end{array}$ & - & 32 & 20 & 37 \\
\hline
\end{tabular}

${ }^{1}$ High $\mathrm{CO}_{2}$ removal effect due to three-stage contact of water and air.

Since the method of simplified aeration does not always provide the required effects of $\mathrm{CO}_{2}$ removal (not more than $40 \mathrm{mg} / \mathrm{dm}^{3}$ ) at its increased concentrations in underground water (Table 1.), it is necessary to introduce high-efficiency degassers into technological diagrams [39].

\subsection{Analysis of water degassing methods}

M.S. Shkrob investigated processes of removal of the dissolved carbonic acid and oxygen at water treatment in power system, F.G. Prokhorov [21], A.P. Mamet , D.P. Yelizarov, V.A. Permyakov [40], V.S. Galustov [41, 42], I .K. Grishuk [43], I.G. Komarchev [44], V.I. Sharapov, M.A. Sivukhina [10], etc. The essential difference of methods of decontamination in power system - full removal of the dissolved gases at the high temperature of the conditioned water $\left(60-100{ }^{\circ} \mathrm{C}\right)$ with the transition to a vaporous state. 
In domestic drinking water supply, physical methods are used not only to achieve minimum gas content (desorption), but also to saturate the water with air oxygen (absorption) [12, 39, 45].

Basic studies on the widely used bubbling degassers, fan and contact cooling towers in the water supply were carried out by A.A. Kastalski [46], studies on removal of $\mathrm{CO}_{2}$ on spray plants - L.P. Rumyantseva [47]. V.V. Dzyubo, L.I. Alferova [12, 48], Yu.L. Skolubovich [49], N.D. Artemenok [50], D.V. Glazkov [51], V.A. Suchkov Zhulin, O.V. Bolotova, L.V.Belova [52, 53, 54, 55], etc.

Simplified aeration methods are characterized by structural simplicity, technological reliability and low cost. However, due to the low efficiency of carbon dioxide removal, it is recommended for use at initial concentrations of $\mathrm{CO}_{2}$ not more than $50 \mathrm{mg} / \mathrm{dm}^{3}[38,58]$.

Free pouring is a stepped cascade, pouring from various heights into a pocket, central channel, or on the open surface of the filter, in which case there are minimal effects of carbon dioxide content reduction due to small areas of the contact surface of water and air, short-term contact of them. V. V. Dzjubo, L. I. Alferova recommend to use free pouring on the water surface (or through the water drain) from the height of $0.4-0.5 \mathrm{~m}$ at the initial concentration of carbon dioxide in water not more than $20 \mathrm{mg} / \mathrm{dm}^{3}$, and spraying with torch or jets at concentrations from 20 to $50 \mathrm{mg} / \mathrm{dm}^{3}$ [48]. Pouring out of holes in the region due to low groundwater temperatures $\left(1-5^{\circ} \mathrm{C}\right)$ provides no more than $33 \% \mathrm{CO}_{2}$ removal effect [57]. The best results show spray plants, in which water is sprayed from nozzles and holes of perforated pipes on a free surface $[47,57]$ or on a rigid contact layer with a developed surface [12]. According to L.P. Rumyantseva [47], the dispersion of groundwater through the holes gives a high effect of removing $\mathrm{CO}_{2}(80-85 \%)$, which is not achieved in the conditions of the region due to climatic features. The advantages of spray plants include low water consumption for own needs and the possibility of application at any productivities of the iron removal plants.

The efficiency of carbon dioxide removal is significantly increased by spraying water onto the free surface of the filter with forced supply of air (blowing under the flare), according to the authors [12] at rates of pouring out $18-30 \mathrm{~m} / \mathrm{h}$ without blowing, the effect of carbon dioxide removal was $30 \%$, and with forced supply of air under the torch $-70 \%$. Disadvantages of the method are noted - metal consumption, necessity to observe optimal values of speeds of air and water flows in order to avoid drip carry-over and growth of iron oxides of structural elements.

Iron removal plants with pressure filters using the method of simplified aeration in the pressure version, the maximum effect of carbon dioxide removal is not more than $20 \%$ [57].

At high initial concentrations of dissolved carbon dioxide in underground water (from $50 \mathrm{mg} / \mathrm{dm}^{3}$ to $200 \mathrm{mg} / \mathrm{dm}^{3}$ ) packed, bubbling, vortex degassers are used.

Packed degassers (fan and contact cooling towers) are used to create a large surface of contact between water and air, to create turbulization of flows [10]. Sprinkling density for packed degassers with regular packing is taken equal to $10-12 \mathrm{~m}^{3} / \mathrm{m}^{2} \cdot \mathrm{h}$ [58], for disordered packing made of Rashig rings $-60 \mathrm{~m}^{3} /\left(\mathrm{m}^{2} \cdot \mathrm{h}\right)$, for wooden chord packing - 45 $\mathrm{m}^{3} / \mathrm{m}^{2} \cdot \mathrm{h}$ [46]. The specific consumption of air by data of A.A. Kastalsky has to make not less than $15-20 \mathrm{~m}^{3} / \mathrm{m}^{3}$, V.I. Sharapov and O.V. Lifshits $[10,59]$, including these values insufficient, recommend $25-40 \mathrm{~m}^{3} / \mathrm{m}^{3}$.

Cooling towers are used at any initial concentrations of dissolved carbon dioxide in areas with mild climatic conditions $[10,46,60]$. At low temperatures of source water and air, the efficiency of carbon dioxide removal at cooling towers is not more than $20-30 \%$ [37], which is due to low values of mass transfer coefficients due to limitation of airspeed and icing of cooling towers in the winter season. In the conditions of the region, the use of 
cooling towers is limited by the initial content of carbon dioxide in water to $100 \mathrm{mg} / \mathrm{dm}^{3}$ and the need to be placed in closed rooms.

Peculiarities of design solutions of bubbling degassers have defined their varieties: conventional bubbler (in free volume) [46, 57], two-section [46], foam degasser [61] and degasser with gravel-crushed stone filling [13, 53].

The first studies to reduce carbon dioxide content on conventional bubbling degassers were carried out by A.P. Mamet [62], according to which the specific air consumption should be taken not more than $10 \mathrm{~kg}$ per $1 \mathrm{~m}^{3}$ of water, which at air density equal to 1.29 $\mathrm{kg} / \mathrm{m}^{3}$ corresponds to the specific air consumption of $7.7 \mathrm{~m}^{3}$ per $\mathrm{m}^{3}$ of water, and the effect of carbon dioxide removal was about $80 \%$. However, Y.L. Skolubovich, D.V. Glazkov, A.A. Ageychik et al. $[49,51]$ argue that even with high specific air consumption, the effects of carbon dioxide removal do not exceed $50-60 \%$. According to the French company Degremon [13] at air supply intensity of $50-100 \mathrm{~m}^{3} / \mathrm{m}^{2} \cdot \mathrm{h}$ the effect of carbon dioxide removal will be $65-75 \%$.

In the conditions of the region, the use of bubbling degassers in the free volume is limited by the initial concentration of carbon dioxide in water not more than $100 \mathrm{mg} / \mathrm{dm}^{3}$ [52].

In order to increase the effect of carbon dioxide removal on the bubbling degassers, A.A. Kastalski proposed the design of a two-section degasser consisting of two identical sections mounted on top of each other. The treated water is sprayed in the upper part of the section and, in contact with the flow of rising air, flows, accumulates in the lower part, where it is blown with air, which is uniformly distributed by means of a hole sheet with holes of $2 \mathrm{~mm}$ diameter. Water is supplied to the second section at its overflow through overflow hole through a pipeline where a similar cycle is repeated. The maximum effect of removal of carbonic acid was $80 \%$ at the consumption of water of $60 \mathrm{~m} 3 / \mathrm{sq} . \mathrm{m} \cdot \mathrm{h}$ and values of specific consumption of air of $9-10 \mathrm{~m}^{3} / \mathrm{m}^{3}$ [46]. Despite the claimed effects of $\mathrm{CO}_{2}$ removal, the proposed degasser is not widely used due to the complexity of the design and metal consumption.

A. G. Zhulin, O.V. Bolotova investigated the design of gravel-crushed stone degasser [53], in which activation of mass transfer takes place due to loading, turbulization zones are created in small interpore space and long-term contact of water with air is provided. The maximum effect of removal of carbonic acid was $80 \%$ lasting purge no more than 5 minutes, values of specific consumption of air of $4-6 \mathrm{~m}^{3} / \mathrm{m}^{3}$, loading layer height to $1 \mathrm{~m}$. Low speeds of the movement of water and periodic clogging of a layer by iron oxides are carried to the shortcomings of the bubbler.

In a foam-type degasser, water flows in a thin layer along the grid and foams by the transverse flow of air supplied through the grid openings. Despite the high effect of carbon dioxide removal - 97\%, the degasser was not used due to low productivity (up to $100 \mathrm{~m}^{3} / \mathrm{h}$ ) and difficulties in operation $[10,17,61]$.

The water supply of the Western-Siberian region uses an aerator-degasser of vortex type, proposed by V.V. Jubo. The principle of operation of the structure is based on the use of the centrifugal-vortex motion of drip rain and air, according to the author, the effect of carbon dioxide removal was $80-91 \%$ at the initial concentration of $180 \mathrm{mg} / \mathrm{dm}^{3}$. The advantage of this degasser is the reduction of the water treatment time to $3-5$ minutes with high efficiency, the disadvantage is the probability of drip removal and relatively high energy consumption [48].

Analysis of existing water degassing structures (Table 2) showed that the design of the bubbling degasser in the free volume allows it to be used as a basis for research on the intensification of carbon dioxide desorption process. 


\section{Conclusions}

The negative effect of carbon dioxide in the water on water purification processes is shown. The extensive use of water degassers in various water purification technologies demonstrates the need to develop new designs as well as design techniques.

When choosing the optimal degasser (aerator), the following factors should be taken into account: productivity and efficiency of the design, complexity of performing optimal operating parameters, the volume of resources spent during operation, cost. Analysis of existing decontamination methods is carried out to remove carbon dioxide. The data are summarised and shown in the comparative table.

Table 2. Physical methods of water degassing.

\begin{tabular}{|c|c|c|c|c|c|c|}
\hline $\begin{array}{l}\text { Degassin } \\
\text { g Method }\end{array}$ & $\begin{array}{c}\text { Region } \\
\text { Application }\end{array}$ & Principle Actions & $\begin{array}{c}\text { Effects } \\
\text { Degassing }\end{array}$ & Advantages & Disadvantages & $\begin{array}{l}\text { Refe } \\
\text { rence }\end{array}$ \\
\hline 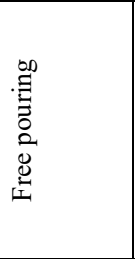 & $\begin{array}{c}\text { Water } \\
\text { supply } \\
\mathrm{CO}_{2} \leq 50 \\
\mathrm{mg} / \mathrm{dm}^{3} \\
\mathrm{CO}_{2} \leq 20 \\
\mathrm{mg} / \mathrm{dm}^{3}\end{array}$ & $\begin{array}{l}\text { Having poured out } \\
\text { water jets over } \\
\text { Filter surface } \\
\text { To ensure contact } \\
\text { of water with air }\end{array}$ & $33 \%$ & $\begin{array}{c}\text { - Used for } \\
\text { stations of } \\
\text { any capacity; } \\
\text { - Do not } \\
\text { require water } \\
\text { consumption } \\
\text { for their own } \\
\text { needs }\end{array}$ & $\begin{array}{c}\text { - Minor } \\
\text { Delete effects } \\
\text { Carbon dioxide at } \\
\text { low groundwater } \\
\text { temperatures }\end{array}$ & $\begin{array}{l}{[12],} \\
{[47],} \\
{[57]}\end{array}$ \\
\hline 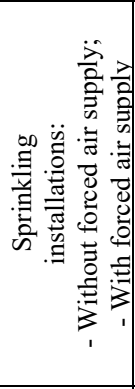 & $\begin{array}{c}\text { Water } \\
\text { supply } \\
\mathrm{CO}_{2} \leq 50 \\
\mathrm{mg} / \mathrm{dm}^{3} \\
\mathrm{CO}_{2} \leq 100 \\
\mathrm{mg} / \mathrm{dm}^{3}\end{array}$ & $\begin{array}{l}\text { Spray over water } \\
\text { surface under the } \\
\text { residual head. } \\
\text { Low-pressure air } \\
\text { supply for spray } \\
\text { water flare }\end{array}$ & $30-70 \%$ & $\begin{array}{l}\text { - Used for } \\
\text { stations of } \\
\text { any capacity; } \\
\text { - Do not } \\
\text { require water } \\
\text { consumption } \\
\text { for their own } \\
\text { needs; } \\
\text { - Significant } \\
\text { carbon } \\
\text { removal } \\
\text { effects } \\
\end{array}$ & $\begin{array}{c}\text { - Metal } \\
\text { consumption, the } \\
\text { complexity of } \\
\text { pipeline isolation; } \\
\text { - Drip carry-over; } \\
\text { - Iron oxide } \\
\text { growth of } \\
\text { structural } \\
\text { elements }\end{array}$ & $\begin{array}{l}12], \\
{[29],} \\
{[47]}\end{array}$ \\
\hline 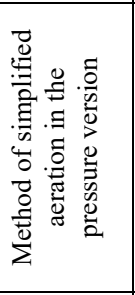 & $\begin{array}{c}\text { Water } \\
\text { supply } \\
\mathrm{CO}_{2} \leq 50 \\
\mathrm{mg} / \mathrm{dm}^{3}\end{array}$ & $\begin{array}{c}\text { Air is introduced } \\
\text { into the pipe (or } \\
\text { mixer) } \\
\text { Before the filters. } \\
\text { The carbon dioxide } \\
\text { removal process } \\
\text { occurs in } \\
\text { conjunction with } \\
\text { aeration }\end{array}$ & $15-20 \%$ & $\begin{array}{l}\text { - Ease of use } \\
\text { of equipment; } \\
\text { - Easy } \\
\text { operation and } \\
\text { cost-effective }\end{array}$ & $\begin{array}{c}\text { Low carbon } \\
\text { removal effects; } \\
\text { - Air conditioning } \\
\text { of filters loading }\end{array}$ & $\begin{array}{l}{[48],} \\
{[57]}\end{array}$ \\
\hline 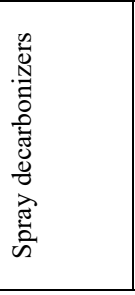 & $\begin{array}{c}\text { Water } \\
\text { treatment } \\
\text { In thermal } \\
\text { power } \\
\text { engineering } \\
\mathrm{CO}_{2} \leq 100 \\
\mathrm{mg} / \mathrm{dm}^{3}\end{array}$ & $\begin{array}{c}\text { Decarbonizer is } \\
\text { divided into } \\
\text { contact and } \\
\text { separation zones } \\
\text { by partition. } \\
\text { Spraying water } \\
\text { with nozzles. Air is } \\
\text { ejected by sprayed } \\
\text { water } \\
\end{array}$ & $70-80 \%$ & $\begin{array}{l}\text { Significant } \\
\text { carbon } \\
\text { removal } \\
\text { effects }\end{array}$ & $\begin{array}{c}\text { - Metal } \\
\text { consumption; } \\
\text { - The complexity } \\
\text { of pipe isolation }\end{array}$ & $\begin{array}{l}{[10],} \\
{[29]}\end{array}$ \\
\hline
\end{tabular}




\begin{tabular}{|c|c|c|c|c|c|c|}
\hline $\begin{array}{l}\text { Degassin } \\
\text { g Method }\end{array}$ & $\begin{array}{c}\text { Region } \\
\text { Application }\end{array}$ & Principle Actions & $\begin{array}{c}\text { Effects } \\
\text { Degassing }\end{array}$ & Advantages & Disadvantages & $\begin{array}{l}\text { Refe } \\
\text { rence }\end{array}$ \\
\hline 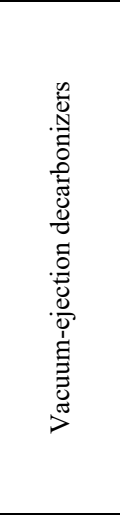 & $\begin{array}{l}\text { Water } \\
\text { supply, } \\
\text { Water } \\
\text { treatment in } \\
\text { thermal } \\
\text { power } \\
\text { engineering } \\
\mathrm{CO}_{2}>100 \\
\mathrm{mg} / \mathrm{dm}^{3}\end{array}$ & $\begin{array}{l}\text { The main ejector } \\
\text { element consists of } \\
\text { the vacuum-spray } \\
\text { head. Vacuum } \\
\text { zones are created } \\
\text { inside the head, as } \\
\text { a result of which } \\
\text { external air is } \\
\text { ejected through } \\
\text { gaps. Water } \\
\text { temperature } 35-42 \\
{ }^{\circ} \mathrm{C}\end{array}$ & $80-95 \%$ & $\begin{array}{l}\text { - Absence of } \\
\text { air supply } \\
\text { equipment; } \\
\text { - High effect } \\
\text { of carbon } \\
\text { dioxide } \\
\text { removal } \\
\text { (residual } \\
\text { carbon } \\
\text { dioxide } \\
\text { content 3- } \\
5 \mathrm{mg} / \mathrm{dm} 3 \text { ) }\end{array}$ & $\begin{array}{l}\text { - High height of } \\
\text { ejectors makes } \\
\text { installation and } \\
\text { maintenance } \\
\text { difficult; } \\
\text { - The icing of } \\
\text { ejectors is } \\
\text { observed in } \\
\text { winter conditions; } \\
\text { - High power } \\
\text { consumption to } \\
\text { create the } \\
\text { required head } \\
\text { before nozzles } \\
\text { (more than 25-35 } \\
\text { m) }\end{array}$ & {$[63]$} \\
\hline 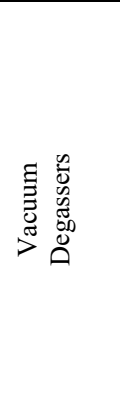 & $\begin{array}{c}\text { Water } \\
\text { treatment } \\
\text { In thermal } \\
\text { power } \\
\text { engineering } \\
\mathrm{CO}_{2}=20 \\
\mathrm{mg} / \mathrm{dm}^{3}\end{array}$ & $\begin{array}{l}\text { Operating } \\
\text { principle - } \\
\text { reduction of } \\
\text { boiling point at } \\
\text { pressure } 0.028- \\
0.039 \mathrm{MPa}\end{array}$ & $100 \%$ & $\begin{array}{l}\text { Complete } \\
\text { removal of all } \\
\text { dissolved } \\
\text { gases } \\
\text { (Carbon } \\
\text { dioxide and } \\
\text { oxygen) }\end{array}$ & $\begin{array}{l}\text { - Considerable } \\
\text { energy } \\
\text { consumption for } \\
\text { vacuum creation } \\
\text { and maintenance; } \\
\text { - The difficulty of } \\
\text { adjustment and } \\
\text { operation due to } \\
\text { increased } \\
\text { requirements to } \\
\text { the tightness of } \\
\text { pipes and valves }\end{array}$ & $\begin{array}{c}\text { Ош } \\
\text { ибка } \\
\text { И } \\
\text { Ист } \\
\text { очн } \\
\text { ик } \\
\text { ссы } \\
\text { лки } \\
\text { не } \\
\text { найд } \\
\text { ен.], } \\
{[21]}\end{array}$ \\
\hline 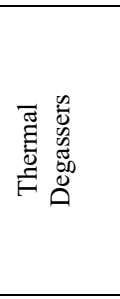 & $\begin{array}{c}\text { Water } \\
\text { treatment } \\
\text { In thermal } \\
\text { power } \\
\text { engineering } \\
\mathrm{CO}_{2}=20 \\
\mathrm{mg} / \mathrm{dm}^{3}\end{array}$ & $\begin{array}{l}\text { Water in the } \\
\text { deaeration column, } \\
\text { flowing through } \\
\text { the trays in } \\
\text { countercurrent } \\
\text { with steam, is } \\
\text { heated to } 103-104 \\
{ }^{\circ} \mathrm{C} \text { and released } \\
\text { from gases }\end{array}$ & $100 \%$ & $\begin{array}{l}\text { Complete } \\
\text { removal of all } \\
\text { dissolved } \\
\text { gases } \\
\text { (Carbon } \\
\text { dioxide and } \\
\text { oxygen) }\end{array}$ & $\begin{array}{l}\text { - The heating } \\
\text { medium is steam } \\
\text { generated during } \\
\text { operation of } \\
\text { steam boilers }\end{array}$ & {$[64]$} \\
\hline 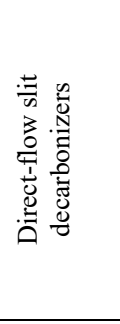 & $\begin{array}{c}\text { Water } \\
\text { treatment } \\
\text { In thermal } \\
\text { power } \\
\text { engineering } \\
\mathrm{CO}_{2} \leq 100 \\
\mathrm{mg} / \mathrm{dm}^{3}\end{array}$ & $\begin{array}{l}\text { Spraying of water } \\
\text { heated to } \mathrm{t}=98- \\
104{ }^{\circ} \mathrm{C} \text { through } \\
\text { slot nozzles under } \\
\text { pressure from } 0.25 \\
\text { to } 0.59 \mathrm{MPa} \text {. This } \\
\text { increases the } \\
\text { contact surface of } \\
\text { the phases }\end{array}$ & $\begin{array}{c}41-99 \% \\
\text { (depends } \\
\text { on } \\
\text { pressure) }\end{array}$ & $\begin{array}{l}\text { - High effect } \\
\text { of carbon } \\
\text { dioxide } \\
\text { reduction; } \\
\text { - Overall } \\
\text { dimensions } \\
\text { and weight } \\
\text { less than that } \\
\text { of packed } \\
\text { degassers } \\
\end{array}$ & $\begin{array}{l}\text { - Water heating is } \\
\text { required; } \\
\text { - High pressure } \\
\text { must be } \\
\text { maintained before } \\
\text { the decarbonizer; } \\
\text { - Increased energy } \\
\text { costs }\end{array}$ & {$[28]$} \\
\hline
\end{tabular}




\begin{tabular}{|c|c|c|c|c|c|c|}
\hline $\begin{array}{l}\text { Degassin } \\
\text { g Method }\end{array}$ & $\begin{array}{c}\text { Region } \\
\text { Application }\end{array}$ & Principle Actions & $\begin{array}{c}\text { Effects } \\
\text { Degassing }\end{array}$ & Advantages & Disadvantages & $\begin{array}{l}\text { Refe } \\
\text { rence }\end{array}$ \\
\hline 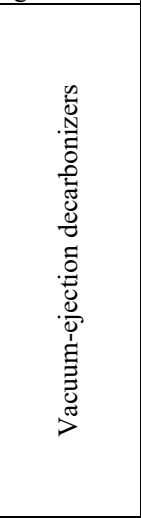 & $\begin{array}{c}\text { Water } \\
\text { supply, } \\
\text { Water } \\
\text { treatment in } \\
\text { thermal } \\
\text { power } \\
\text { engineering } \\
\mathrm{CO}_{2}>100 \\
\mathrm{mg} / \mathrm{dm}^{3}\end{array}$ & $\begin{array}{l}\text { The main ejector } \\
\text { element consists of } \\
\text { the vacuum-spray } \\
\text { head. Vacuum } \\
\text { zones are created } \\
\text { inside the head, as } \\
\text { a result of which } \\
\text { external air is } \\
\text { ejected through } \\
\text { gaps. Water } \\
\text { temperature } 35-42 \\
{ }^{\circ} \mathrm{C}\end{array}$ & $80-95 \%$ & $\begin{array}{l}\text { - Absence of } \\
\text { air supply } \\
\text { equipment; } \\
\text { - High effect } \\
\text { of carbon } \\
\text { dioxide } \\
\text { removal } \\
\text { (residual } \\
\text { carbon } \\
\text { dioxide } \\
\text { content 3- } \\
5 \mathrm{mg} / \mathrm{dm} 3 \text { ) }\end{array}$ & $\begin{array}{l}\text { - High height of } \\
\text { ejectors makes } \\
\text { installation and } \\
\text { maintenance } \\
\text { difficult; } \\
\text { - The icing of } \\
\text { ejectors is } \\
\text { observed in } \\
\text { winter conditions; } \\
\text { - High power } \\
\text { consumption to } \\
\text { create the } \\
\text { required head } \\
\text { before nozzles } \\
\text { (more than 25-35 } \\
\text { m) }\end{array}$ & {$[63]$} \\
\hline 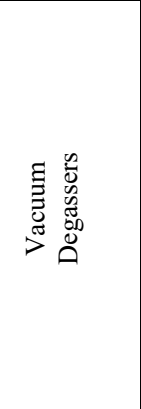 & $\begin{array}{c}\text { Water } \\
\text { treatment } \\
\text { In thermal } \\
\text { power } \\
\text { engineering } \\
\mathrm{CO}_{2}=20 \\
\mathrm{mg} / \mathrm{dm}^{3}\end{array}$ & $\begin{array}{l}\text { Operating } \\
\text { principle - } \\
\text { reduction of } \\
\text { boiling point at } \\
\text { pressure } 0.028- \\
0.039 \mathrm{MPa}\end{array}$ & $100 \%$ & $\begin{array}{l}\text { Complete } \\
\text { removal of all } \\
\text { dissolved } \\
\text { gases } \\
\text { (Carbon } \\
\text { dioxide and } \\
\text { oxygen) }\end{array}$ & $\begin{array}{l}\text { - Considerable } \\
\text { energy } \\
\text { consumption for } \\
\text { vacuum creation } \\
\text { and maintenance; } \\
\text { - The difficulty of } \\
\text { adjustment and } \\
\text { operation due to } \\
\text { increased } \\
\text { requirements to } \\
\text { the tightness of } \\
\text { pipes and valves }\end{array}$ & $\begin{array}{c}\text { Ош } \\
\text { ибка } \\
\text { И } \\
\text { Ист } \\
\text { очн } \\
\text { ик } \\
\text { ссы } \\
\text { лки } \\
\text { не } \\
\text { найд } \\
\text { ен.], } \\
{[21]}\end{array}$ \\
\hline 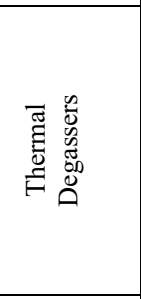 & $\begin{array}{c}\text { Water } \\
\text { treatment } \\
\text { In thermal } \\
\text { power } \\
\text { engineering } \\
\mathrm{CO}_{2}=20 \\
\mathrm{mg} / \mathrm{dm}^{3}\end{array}$ & $\begin{array}{c}\text { Water in the } \\
\text { deaeration column, } \\
\text { flowing through } \\
\text { the trays in } \\
\text { countercurrent } \\
\text { with steam, is } \\
\text { heated to } 103-104 \\
{ }^{\circ} \mathrm{C} \text { and released } \\
\text { from gases }\end{array}$ & $100 \%$ & $\begin{array}{l}\text { Complete } \\
\text { removal of all } \\
\text { dissolved } \\
\text { gases } \\
\text { (Carbon } \\
\text { dioxide and } \\
\text { oxygen) }\end{array}$ & $\begin{array}{l}\text { - The heating } \\
\text { medium is steam } \\
\text { generated during } \\
\text { operation of } \\
\text { steam boilers }\end{array}$ & {$[64]$} \\
\hline 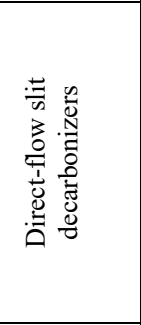 & $\begin{array}{c}\text { Water } \\
\text { treatment } \\
\text { In thermal } \\
\text { power } \\
\text { engineering } \\
\mathrm{CO}_{2} \leq 100 \\
\mathrm{mg} / \mathrm{dm}^{3}\end{array}$ & $\begin{array}{l}\text { Spraying of water } \\
\text { heated to } \mathrm{t}=98- \\
104{ }^{\circ} \mathrm{C} \text { through } \\
\text { slot nozzles under } \\
\text { pressure from } 0.25 \\
\text { to } 0.59 \mathrm{MPa} \text {. This } \\
\text { increases the } \\
\text { contact surface of } \\
\text { the phases }\end{array}$ & $\begin{array}{l}41-99 \% \\
\text { (depends } \\
\text { on } \\
\text { pressure) }\end{array}$ & $\begin{array}{l}\text { - High effect } \\
\text { of carbon } \\
\text { dioxide } \\
\text { reduction; } \\
\text { - Overall } \\
\text { dimensions } \\
\text { and weight } \\
\text { less than that } \\
\text { of packed } \\
\text { degassers } \\
\end{array}$ & $\begin{array}{l}\text { - Water heating is } \\
\text { required; } \\
\text { - High pressure } \\
\text { must be } \\
\text { maintained before } \\
\text { the decarbonizer; } \\
\text { - Increased energy } \\
\text { costs }\end{array}$ & {$[28]$} \\
\hline 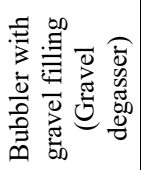 & $\begin{array}{c}\text { Water } \\
\text { supply } \\
\mathrm{CO}_{2} \leq 200 \\
\mathrm{mg} / \mathrm{dm}^{3}\end{array}$ & $\begin{array}{l}\text { Blowing water } \\
\text { with air through } \\
\text { the loading layer } \\
\text { (gravel, crushed } \\
\text { stone) }\end{array}$ & $75-80 \%$ & $\begin{array}{l}\text { High effect of } \\
\text { carbon } \\
\text { dioxide } \\
\text { removal }\end{array}$ & $\begin{array}{l}\text { Clogging of } \\
\text { charge with iron } \\
\text { oxides }\end{array}$ & $\begin{array}{l}{[13],} \\
{[38],} \\
{[53]}\end{array}$ \\
\hline
\end{tabular}




\begin{tabular}{|c|c|c|c|c|c|c|}
\hline $\begin{array}{l}\text { Degassin } \\
\text { g Method }\end{array}$ & $\begin{array}{c}\text { Region } \\
\text { Application }\end{array}$ & Principle Actions & $\begin{array}{c}\text { Effects } \\
\text { Degassing }\end{array}$ & Advantages & Disadvantages & $\begin{array}{l}\text { Refe } \\
\text { rence }\end{array}$ \\
\hline 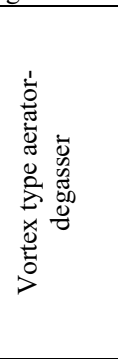 & $\begin{array}{c}\text { Water } \\
\text { supply } \\
\mathrm{CO}_{2} \leq 200 \\
\mathrm{mg} / \mathrm{dm}^{3}\end{array}$ & $\begin{array}{l}\text { Vortex low- } \\
\text { pressure device, in } \\
\text { which water with } \\
\text { incoming airflow } \\
\text { is distributed in the } \\
\text { form of the thin } \\
\text { film on the internal } \\
\text { surface of the } \\
\text { device with the } \\
\text { transition to } \\
\text { raindrops }\end{array}$ & $80-91 \%$ & $\begin{array}{c}\text { Allows you to } \\
\text { reduce your } \\
\text { time several } \\
\text { times } \\
\text { Water } \\
\text { treatment } \\
\text { compared to } \\
\text { bubbling } \\
\text { degassers }\end{array}$ & $\begin{array}{l}\text { Compliance with } \\
\text { optimal operating } \\
\text { parameters to } \\
\text { prevent drip } \\
\text { discharge of } \\
\text { treated water from } \\
\text { the apparatus }\end{array}$ & $\begin{array}{c}\text { [Ош̈ } \\
\text { ибка } \\
! \\
\text { Ист } \\
\text { очн } \\
\text { ик } \\
\text { ссы } \\
\text { лки } \\
\text { не } \\
\text { найд } \\
\text { ен.] }\end{array}$ \\
\hline 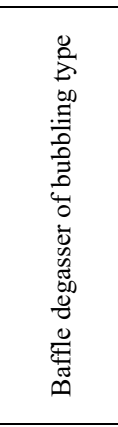 & $\begin{array}{c}\text { Water } \\
\text { supply } \\
\mathrm{CO}_{2} \leq 200 \\
\mathrm{mg} / \mathrm{dm}^{3}\end{array}$ & $\begin{array}{c}\text { Water and air } \\
\text { move in } \\
\text { countercurrent } \\
\text { mode in free } \\
\text { volume. Several } \\
\text { rows of partitions } \\
\text { with holes } \\
\text { covering part of } \\
\text { the live section are } \\
\text { installed on the } \\
\text { path of the water- } \\
\text { air mixture } \\
\text { movement. }\end{array}$ & $75-80 \%$ & $\begin{array}{l}\text { - High effect } \\
\text { of carbon } \\
\text { dioxide } \\
\text { removal; } \\
\text { - High liquid } \\
\text { flow rates in } \\
\text { the degasser } \\
\text { up to } 120 \mathrm{~m} / \mathrm{h}\end{array}$ & $\begin{array}{l}\text { The degasser, } \\
\text { depending on the } \\
\text { number of rows of } \\
\text { partitions, has a } \\
\text { significant height }\end{array}$ & $\begin{array}{l}{[54],} \\
{[55]}\end{array}$ \\
\hline 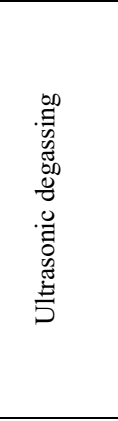 & $\begin{array}{l}\text { Water } \\
\text { supply, } \\
\text { metallurgy, } \\
\text { oil refining, } \\
\text { food and } \\
\text { pharmaceut } \\
\text { ical } \\
\text { enterprises, } \\
\text { thermal } \\
\text { power }\end{array}$ & $\begin{array}{l}\text { Under the } \\
\text { influence of } \\
\text { ultrasonic } \\
\text { oscillations, the } \\
\text { liquid flowing } \\
\text { through the } \\
\text { deaerator is } \\
\text { degassed }\end{array}$ & - & $\begin{array}{l}\text { This method } \\
\text { is at the stage } \\
\text { of } \\
\text { development } \\
\text { in the water } \\
\text { supply. }\end{array}$ & $\begin{array}{c}\text { - Requires } \\
\text { preliminary } \\
\text { heating of water } \\
\text { Up to } 30-80{ }^{\circ} \mathrm{C} \text {; } \\
\text { - Impossibility of } \\
\text { making } \\
\text { chemically related } \\
\text { forms of } \mathrm{CO}_{2} .\end{array}$ & $\begin{array}{c}{[65],} \\
{[66],} \\
{[О ш і} \\
\text { ибка } \\
\vdots \\
\text { Ист } \\
\text { очн } \\
\text { ик } \\
\text { ссы } \\
\text { лки } \\
\text { не } \\
\text { найд } \\
\text { ен.] }\end{array}$ \\
\hline
\end{tabular}

\section{References}

1. R.A. Bailey, H.M. Clark, J.P. Ferris, S. Krause, R.L. Strong, The environmental chemistry of some important elements. Chem. of the Envir., 347-414 (2002) https://doi.org/10.1016/B978-012073461-0/50057-0

2. K. Nakata, T. Hasegawa, D.K. Solomon, K. Miyakawa, Y. Tomioka, T. Ohta, T. Matsumoto, K. Hama, T. Iwatsuki, M. Ono, A. Marui, Degassing behavior of noble gases from groundwater during groundwater sampling. Appl. Geochem. (2019) https://doi.org/10.1016/j.apgeochem.2019.03.007

3. C.R. Fitts, Groundwater Chem.. Groundwater Scie., 421-497 https://doi.org/10.1016/B978-0-12-384705-8.00010-8

4. Degremont, Water Treatment Handbook, 6th edn. Lavoisier, Paris (1991)

5. H. Tan, W. He, H. Han, Y. Lu, N. Zhang, Spec. of iron and develop. of iron corrosion scales in drink. water distrib. Syst. Desalination and Water Treatment, 56:3, 646654 (2015) https://doi.org/10.1080/19443994.2014.941303 
6. B. Durham, Membrane pretreatment of reverse osmosis - Long term experience on difficult waters. Desalination, 110(1-2), 49-58 (1997) https://doi.org/10.1016/S00119164(97)00083-0

7. L. Birnhack, O. Lahav, Post-Treatment of Desalinated Water-Chemistry, Design. Eng., and Implement. Sustainable Desalination Handbook, 305-350 (2018) https://doi.org/10.1016/B978-0-12-809240-8.00008-3

8. P. Mouchet, From Conventional to Biological Removal of Iron and Manganese in France. J. - Amer. Water Works Assoc., 84(4), 158-167 (1992) https://doi.org/10.1002/j.1551-8833.1992.tb07342.x.

9. P.R. Roberge, Handbook of corrosion engineering. New York: McGraw-Hill (1999)

10. A. Bahadori, Corrosion in Pipelines and Piping Systems. Oil and Gas Pipelines and Piping Syst., 395-481 (2017) https://doi.org/10.1016/B978-0-12-803777-5.00015-0.

11. Z. Ahmad, CONCRETE CORROSION. Princ. of Corr. Eng. and Corr. Cont., 609646 (2006) https://doi.org/10.1016/B978-075065924-6/50013-1.

12. M.J. Brandt, K.M. Johnson, A.J. Elphinston, D.D. Ratnayaka, Specialized and Advanced Water Treatment Processes. Twort's Water Supply, 407-473 (2017) https://doi.org/10.1016/B978-0-08-100025-0.00010-7. 